\title{
Progress towards a World-Class Research University status: The case of Nanjing Agricultural University
}

\author{
Wanjiru Ruth Irungu ${ }^{1}$, Xiaoguang Liu ${ }^{1}$, Chuyu Han $^{1}$, Alvin Bomer ${ }^{1} \&$ Wambui Ann Wanjiru ${ }^{1}$ \\ ${ }^{1}$ College of Public Administration, Nanjing Agricultural University, China \\ Correspondence: Liu Xiaoguang, College of Public Administration, Nanjing Agricultural University, China
}

Tel: 86-137-7064-1997. E-mail: liuxg@ njau.edu.cn

$\begin{array}{ll}\text { Received: November 10, } 2019 & \text { Accepted: December 11, } 2019 \quad \text { Online Published: December 23, } 2019 \\ \text { doi:10.5539/hes.v10n1p72 } & \text { URL: https://doi.org/10.5539/hes.v10n1p72 }\end{array}$

\begin{abstract}
The concept of "world-class university" has been there for some time, and everyone wants a world-class university, and no country feels it can do without one. This battle to develop world-class universities lies not only in the gained status but also in the symbolic role of such universities. Universities exist mainly for research and dissemination of knowledge, which have become critical drivers of economic growth. For this reason, world-class research universities are recognized as central institutions in the $21^{\text {st }}$ century economies. This recognition comes with pressure for universities to rethink their research activities and with the need to raise their research status to that of internationally accepted world-class universities. However, in order to attain the world-class research status, there is a need to sustain the efforts being put in place at both national and university levels. This study analyzed university data over nine years, from 2008 to 2016. It examined how Nanjing Agricultural University has strived to sustain its efforts towards attaining world-class research status. The results reveal that consistency and sustainability have resulted in excellence in research and increased research production. The conclusion is that the sustainability of the efforts significantly increases research production and excellence.
\end{abstract}

Keywords: China, Research University, World-class university, sustainability

\section{Introduction}

Sustainability of universities has not been adequately addressed, especially within the domains of strategic perspectives (Hussain et al., 2019). This complex problem of university sustainability implies a big challenge for countries and educators to implement important strategies regarding developing world-class research universities (Z. Liu, Moshi, \& Awuor, 2019). Studies focusing on actual sustainability of policies at national and institutional levels are rare, as most focus on how to create world-class universities and how to deal with challenges facing the creation of world-class universities (Tierney, 2014). Few details regarding the sustainability or the process of transformation in Chinese universities have been explored. This study therefore, endeavours to fill this void by gathering a unique dataset that provides detailed information on research support and outcomes in Nanjing Agricultural University, one of the most research-intensive higher education institutions in China and which is funded and supervised by China's Ministry of Education. In addition to our unique data and research context, this study contributes to the literature on research funding and production in a number of important ways.

The concept of "world-class university" has been there for some time, and as observed by P. Altbach (2003), everyone wants a world-class university, and no country feels it can do without one. As such, various governments, as well as various stakeholders across the globe, have placed the issue of World-class universities high on their agenda in the past few decades (W. Liu, 2018; Z. Liu, Moshi, \& Awuor, 2019; Shen, 2015). Both developed and developing countries, regions and higher education institutions in different parts of the world have joined this battle for excellence (Q. Wang, Cheng, \& Liu, 2012).

The term world-class research university has been defined by different scholars referring to various aspects of merit in higher education research. Common themes include: excellence in research, an intellectually stimulating environment, dynamic knowledge and technology transfer, and adequate facilities and funding (P. G. Altbach \& Salmi, 2011; Yang \& Welch, 2012). Among the many existing definitions within the field of higher education, we focus on the definition by P. Altbach (2003). He argued that "world-class" means ranking among the 
foremost in the world; of international standard of excellence. He then points out some relevant characteristics necessary for world-class status: excellence in research, that is well-recognized and that pushes back the frontiers of knowledge; an atmosphere of intellectual excitement; adequate funding; and good governance.

Universities exist mainly for research and dissemination of knowledge. According to Czarniewski (2015), research generates new knowledge that is the fundamental source of most innovation and creativity, which in turn becomes a critical driver of economic growth (Branigan, Harvie, Michalas, and Ramezani Khansari (2016). For this reason, World-class research universities are considered central institutions in the $21^{\text {st }}$ century economies (P. G. Altbach \& Salmi, 2011). The growth of these economies is increasingly based on research-based knowledge (Mintrom, 2008; Salem, 2014). As a result, research universities in their roles as knowledge producers are increasingly recognized to have a pivotal role to play in supporting regional economic development (Rossi \& Rosli, 2015). This recognition comes with pressure for universities to rethink their research activities (Mintrom, 2008), and with the need to raise their research status to that of internationally accepted world-class universities (Tayeb, 2016).

For universities to achieve this milestone, one factor agreed upon by scholars is the consistency and sustainability of efforts put in place by both governments and universities. Z. Liu et al. (2019) Point out that the path for world-class universities is not something that can be fixed overnight. To achieve success as world-class universities, research and teaching need to be sustained and given room to innovate through faculty and programs. There is a need for the sustainability of efforts, which is crucial in ensuring that these efforts become even more cost-effective and fruitful. Governments and universities throughout the world have significantly implemented various policies, huge projects and substantial initiatives to the governance, function, missions, and performance improvement of universities for world-class research status. Z. Liu et al. (2019), for instance, notes that the rise of Universities in China, Singapore and Belgium to world-class universities is attributed to the sustainability of their efforts towards excellence. During the past eight years, these countries have stimulated and constantly supported their domestic universities to achieve world-class status. Japan, in contrast, has experienced a drop in world ranking which according to Z. Liu et al. (2019) are due to inconsistency, whereby the financial crisis has prevented additional funding expected for making significant progress on the university research activities.

The battle to create world-class universities has its roots not just in financial motives, the gained status, or the strategic advantage in both quality and quantity (Marginson, 2017), but also in the symbolic role of such universities (Bejinaru \& Prelipcean, 2017). Cremonini, Westerheijden, Benneworth, and Dauncey (2014) noted that countries that felt underrepresented in the world-class university rankings have strived to create special approaches to raise national performance rankings.

\subsection{Research Objective}

To gather an overview of the performance of Nanjing Agricultural University, a research-intensive university in China along the following key indicators: adequate funding, excellence in research (publications, awards), internationalization (research collaboration), and knowledge transfer (conferences, patents).

\subsection{Justification of the Study}

1. The study will form a basis for the university to assess its achievements towards world-class university status.

2. The study will inform the university on its strong and weak areas and therefore help in devising new strategies in the battle for world-class research university status.

3. The study is expected to provide a kind of benchmark for other universities striving to gain world-class status in research.

4. The study may also serve as a basis for further studies.

\section{Literature Review}

\subsection{Important Considerations Related To World-class Research University Status}

The concept of "world-class" has been greatly debated over, especially with regard to what constitutes a world-class university or world-class research university. According to Z. Liu et al. (2019), while the goal of a world-class university is clear, the definition of world-class status is not. This is partly because these terms come from diverse perspectives and different dimensions (Huang, 2015). It is an abstract concept that has different characteristics depending on the context and objective of various universities. Tierney (2014) contends that a world-class research university should have a culture of innovation in their organizations. With respect to characteristics of world-class university, it is emphasized that they include four key aspects: adequate funding, 
excellence in research (publications, awards), internationalization (research collaboration), and knowledge transfer (conferences, patents) (P. Altbach, 2003; P. G. Altbach \& Salmi, 2011; Tsai, 2017; Yang \& Welch, 2012).

\subsubsection{Funding}

Research funding has been cited as the most important element in higher education and highly-impact academic research (Reddy, Xie, \& Tang, 2016). L. Zhang, Bao, and Sun (2016) have reported that most studies on research production have shown that research production is a function of various financial resources. Financial resources, for example, research expenditures, are directly related to research activities and thus an obvious factor affecting research production. Research expenditures are also used to predict future research capacity of universities, which according to B. Zhao (2018), affect the economic growth and competitiveness of universities and their host communities and states. (L. Zhang et al., 2016) therefore find that adequate and consistent research funding will lead to a consistent research output.

\subsubsection{Excellence in Research}

\subsubsection{Publications}

The importance of research publications lies in the fact that 'publish or perish' has been a much-cherished tradition of academia across all disciplines and national contexts (Tan \& Goh, 2014). The strengthening of this tradition has become more crucial following the emergence of the knowledge-based economy, which relies on research and knowledge production (Tan \& Goh, 2014). Publications are now significant as measures of research output in a university. Research publications are efficient for assessing research production in a direct way. The number of publications is usually used in the literature to indicate the overall pool of current expertise in an institution and for operationalizing and quantifying research output (L. Zhang et al., 2016).

Further, publications are not only significant as indicators of research output, but also as channels of knowledge and technology transfer, which is crucial in the knowledge-based economies of the $21^{\text {st }}$ century. Publications are effective in ensuring that the contribution to knowledge is widely disseminated (Asongu \& Nwachukwu, 2018). Also, marketing the contribution of knowledge to businesses and third parties is much easier, and the transfer of technology is more likely if the quality of the research has been recognized by peers through a peer-review process and published (Asongu \& Nwachukwu, 2018).

In recent years, in addition to what scientists publish, where they publish has increasingly begun to matter. Journals are now ranked according to their impact factor, which is the average citations in a given year acquired by all articles published in the journal over the two previous years (Stern \& O'Shea, 2019). Journal impact factor, the bibliometric indicator that is most widely used in the evaluation of scientists, is used by funders and employers to make funding and employment decisions (Stern \& O'Shea, 2019). Thus, researchers publishing in high impact factor journals tends to receive more recognition as scholars and hence gain a competitive advantage in faculty positions. Also, in world university rankings, universities with more publications in the highly ranked journals have higher chances of being ranked top.

However, most publication is still disseminated using a process inaugurated in the $17^{\text {th }}$ century, with the noteworthy addition of peer review in the middle of the $20^{\text {th }}$ century (Stern \& O'Shea, 2019). It starts with authors submitting an article to the journal they choose, where editorial selection and peer review conclude in an editorial thumbs-up or thumbs-down decision (Stern \& O'Shea, 2019). This determines if the article is accepted for publication or rejected. It is a long slow process that often delays research publication. It hurts science because research that is not published is equivalent to research that is not done, at least from the viewpoint of the broader scientific community and the public (Stern \& O’Shea, 2019).

\subsubsection{Awards}

Awards are indicators of excellence and research talent, whereby the recipients are selected on a merit-based process. Awards convey appreciation and recognition on the part of colleagues and the public. Thus, academics are very fond of awards, ranging from a multitude of "best paper awards" to the highly esteemed Nobel Prizes (Frey \& Neckermann, 2008). A high number of awards in a faculty or university signifies high research participation among academics.

Further, awards are not only indicators of excellence among faculty, but also function to motivate researchers to perform excellently. In a study done by Tan and Goh (2014), awards in the form of monetary reward incentive schemes introduced in the USM became a major driving force that spurs the number of publications among USM academic staff. The adherents of awards as incentives tend to assume that recognition through receiving awards is an important source of motivation (Frey \& Neckermann, 2008). 
Further, awards are significant to universities since they generate loyalty to the awarding university. Awards show recognition and appreciation of academics, thereby raising intrinsic motivation to do research and generate loyalty to the awarding institution (Frey \& Neckermann, 2008). Therefore, awards as a strategy of rising to world-class status are important for research universities.

\subsubsection{Knowledge Transfer}

Knowledge transfer is defined by Asongu and Nwachukwu (2018) as the transfer of intellectual property rights from the knowledge contributor to a third party, usually a government institution or a business entity. While student enrolment and degree production may be viewed as primary functions in many universities, knowledge transfer is emphasized (Leslie, Slaughter, Taylor, \& Zhang, 2012). Knowledge transfer, according to Kalar and Antoncic (2015), occurs through a wide range of activities, whereby some of these activities are more formal than others. More formal activities are based on intellectual property rights as the main outcomes of universities such as patents, and other less formal activities such as academic conferences. Both patents and academic conferences are important and have been shown to provide an important economic and social value for both academics and industry partners. Thus, knowledge transfer is now a recognized important aspect and indicator for world university rankings.

\subsubsection{Patents}

According to Dillon (2009), Patents are documents that are awarded for the creation, discovery, or improvement of new processes. Apart from functioning to grant inventors the exclusive right to own their inventions (Choi, Jang, Jun, \& Park, 2015), patents are also a symbol of new, useful information that is not obvious to a person with ordinary knowledge in the subject area. They are the main parts of the sustainability of technological developments and knowledge interactions in the current age (Ileritürk \& Kincal, 2018). They are indicators of the exploitation of research results (Hayden, Weiß, Pechriggl, \& Wutti, 2018). Governments grant patents to encourage scientific research and to ensure that the results of this research become part of the public record (Dillon, 2009).

Patents as indicators are important as they not only indicate the innovation intensity of a university, but also measure its research output (Chellaraj, Maskus, \& Mattoo, 2005; Kalanje, 2006). The production of patents, however, is hugely dependent on the actions and services of higher education institutions (Ileritürk \& Kincal, 2018). For instance, adequate research funding will affect research production (innovations), which in turn affects the number of patents produced.

\subsubsection{Academic Conferences}

Academic conferences are sites of globalization of academia, technological innovation, and change, and are representative of the overall picture of higher education (Henderson, 2015). Hickson (2006) holds that conferences provide a forum to observe notable scholars debate with authority about topics important to their discipline. Over time, such presentations stimulate lectures, articles, special issues of journals, and even entire books. Also, sitting in and listening to other's presentations has the added contagion effect of creating excitement and enthusiasm about doing research (Hickson, 2006).

Further, conferences are important channels of knowledge transfer. They are intense cases of information and social linking, where academics interact with one another not only when presenting, but also before, during, and after the conference (Brusilovsky, Oh, López, Parra, \& Jeng, 2017; Nicolson, 2016). These interactions enrich professional knowledge and facilitate knowledge exchange between peers, industry, and community members. The place of conferences in science and academia is thus established and recognized.

In world university rankings, conferences as channels of knowledge transfer are therefore significant. The rate of participation of a university in academic conferences is an indicator of not only its contribution by generating information worth sharing but also its commitment to technology and knowledge transfer. The place of academic conferences in science and academia is established and is thus an important element to maintain in a university.

\subsubsection{Internationalization}

Internationalization is a way of developing world-class universities, whereby multifaceted and multidimensional processes of integrating international, intercultural, and global content and dimensions into higher education research are encouraged (Ota, 2018; Schulte, 2019). International collaboration allows scientists and researchers from different countries to work together with leading experts elsewhere for the production of higher quality research (Veugelers, 2017). In a recent study, Reddy et al. (2016) describe the advantages that come about as a result of collaborations. There will be an exchange of ideas among faculty members who participate in the collaboration. This allows local faculty members both to share their thoughts and experiences and to improve 
their research skills in specific domains. The local faculty participants, in extension, can pass those new research skills and dimensions to their colleagues and students. Thus, universities gain new techniques not only in research but also in teaching and course development.

In addition, collaborations not only bring about knowledge sharing but also co-funding. According to Reddy et al. (2016), research grants can be shared among the participant universities. Thus, sustaining the culture of research collaboration is important for any university to rise to world-class status.

\subsection{Sustainability and Higher Education}

Scholars agree that change does not take place overnight. Thus, the sustainability of efforts put in place to promote research universities into world-class status is crucial and long-term. Sustainability is a term that inherently evokes a concept of preservation and nurturing over time (Toman, 1992). It is the inherent stability of a social organization and its components (Sverdrup \& Svensson, 2002). According to the Cambridge Dictionary, it is the quality of being able to continue over a period of time (Dictionary, n.d.). For economists, sustainability is the maintenance and improvement of standards (Toman, 1992). All these definitions point to the preservation and nurturing over time. Sustainability of efforts in developing world-class universities could, therefore, refer to the stability, nurture and consistency of these efforts over time.

Higher education and sustainability can be related to one another in two ways. On the one side, universities are places that are supposed to teach about sustainability; on the other, universities can themselves become targets of sustainability. The perspective of universities as teaching sites for sustainability is based on the assumed correlation between education, sustainability, and economic growth, whereby economies can only grow if there is continuous higher education. The perspective of the sustainability of university components is based on consistency and nurturing that must take place in the university. Sustainability of university components is in areas such as academic research funding, collaboration outside the university, and internationally and higher education management.

\subsection{World Class University: the Case of China}

\subsubsection{Policy Framework}

The Chinese government, just like its counterparts in the rest of the world, has stated its goal to develop and sustain a university education system of international stature with a number of research universities $(\mathrm{Q}$. H. Wang, Wang, \& Liu, 2011). The government has developed both national and institutional policies and strategies to stimulate the emergence of world-class universities and particularly to build world-class research universities (Huang, 2015). Since China conducted a reform of higher education with the clear goal of building world-class universities, the country has made significant efforts to sustain these reforms.

Creating and sustaining world-class universities is a national strategy devised and guided by the top policymakers (Luo, 2013). The central government of China thus plays a dominant role in this initiative (Ngok \& Guo, 2008). The central government has increasingly given higher priority to advancing the higher education system, seeing it as serving a dominant role in the modernization process and also in economic development $(\mathrm{H}$. Zhang, Patton, \& Kenney, 2013). More recently, beyond these economic benefits, having world-class universities has symbolic importance as China strives to assert its status as a global leader. China well understands that in this global knowledge economy, world-class research universities are central players in the international marketplace of ideas and capacities. Thus, believing that first-class universities increasingly reflect a nation's overall power, the Chinese government is now committed to strategically promoting a group of Chinese universities with the potential to enter the world-class league within a decade and is heavily investing in them (Yang \& Welch, 2012).

In 2015, the Central Party Committee and the State Council in China announced the "Double World-Class Project", which aims to promote and push forward the world-class initiative and the first-class discipline construction (Peters \& Besley, 2018). Song (2018) further notes that this was the first time a systematic plan for world-class universities had been introduced into higher education and also the first time a clear timetable regarding when the goal might be achieved was given. This plan aims to promote a batch of high-level universities and disciplines to enter the world's top ranks and raise the level of innovation in scientific research (Peters \& Besley, 2018). Although this systematic plan for world-class universities is more recent, creating world-class universities has been the dream and pursuit of several generations of China (W. Liu, 2018). The overall development of China's higher education sector had taken place over the years through the implementation of 211 Project and subsequent 985Project (Peters \& Besley, 2018). These projects aimed to create a number of famous research universities and to enhance the international reputation of Chinese 
universities (Song, 2018). Proposed by the State Council in 1991-1993 and officially launched in 1995, the 211 Project is one of the earliest conscious government efforts at raising the research standards of around 100 key universities for the twenty-first century (Zong \& Zhang, 2019). Under the 211 Project, from 1996 to 2000, more than 10 billion yuan extra money was invested in 99 universities (Ngok \& Guo, 2008).

\subsubsection{Government Strategy}

\subsubsection{Overall Plan}

There are three milestones in the plan to promote a batch of high-level universities and disciplines to enter the world's top ranks: by 2020: to develop a number of world-class universities and a group of world-class disciplines; by 2030: to have more universities and disciplines among the best in the world and to have significant improvement in China's overall higher education strength; by 2050: the number and quality of world-class universities and disciplines to be among the best in the world, so that China will have become a higher education power (Peters \& Besley, 2018). This new strategy, apart from just promoting universities and selected disciplines to world-class status, also has a more national needs-driven goal. According to Huang (2017), the plan aims to actively construct and support disciplines with Chinese characteristics, style, and spirit such as Chinese medicine and culture. Towards the realization of the above, Project 985, was launched in 1999 and directly pointed at the goal of universities becoming world-class (Song, 2018). H. Zhang et al. (2013) notes that in percentage terms, the 985 Project is a crucial component of one of the biggest sustained increases of investment in university research in human history. This plan shortlisted 39 universities from 211 Project with the plan of concentrating resources on a batch of flagship universities that were best placed in China to realize world-class ambitions (Zong \& Zhang, 2019). In the more recent "Double World-Class Project" replacing the "985 Project" and the "211 Project", some 42 universities have been selected to be developed into world-class universities and another 95 into universities with world-class disciplines (L. Zhao, 2018).

\subsubsection{Funding}

According to Veugelers (2017), Chinese investment in research and development has risen steadily, surpassing that of other economic giants, the United States, and the European Union. This rise is not an accident but a result of long-sustained strategies to develop China's research infrastructure (Veugelers \& Baltensperger, 2019). Between 2000 and 2015, China more than doubled its national expenditures on research and development from $0.9 \%$ of its GDP to $2.1 \%$, thus almost reaching the OECD average of $2.4 \%$ (Schulte, 2019).

At present, there are 112 key universities in total supported by the 211 Project, and more than 17 billion RMB yuan (equivalent to $£ 1.7$ billion) has since then been spent on the 211 Project universities (Zong \& Zhang, 2019).

\subsubsection{Achievements}

As a result of various strategies the country has put in place, China has made significant improvements in research production. The country is now the second-largest performer of research and development, on a country basis, and accounts for 20 percent of total world research and development (Pang, 2018). China has also been ranked as a top country in terms of patent applications and registered patents. In a study of 202 Programme for International Student Assessment (PISA) participant countries in patent productions, China boasts of $7.6 \%$ of patent families (Ileritürk \& Kincal, 2018). L. Zhang et al. (2016) further observe a rise of $8.35 \%$ annual rate in research production between 2000 and 2010 in a study done on 72 Chinese universities. In a more recent analysis by the Scopus database of international scientific journals, China's proportion of articles jumped from 4 percent in 2000 to 18.6 percent in 2016, topping the US total (Xie \& Freeman, 2019). Further, China has increased its efforts in other areas, such as in internationalization. Veugelers (2017) observes that China is becoming a more important partner for the west for scientific cooperation.

In terms of global rankings, China has seen a steady rise at major global world universities rankings systems such as the Shanghai Jiao Tong ARWU (Academic Ranking of World-Class University), which was created by China's Shanghai Jiaotong University, the Times Higher Education and QS. According to (Huang, 2015), the total number of Chinese universities that were listed among the top 500 in 2004 at the ARWU was only eight, and it had increased to 28 by 2013. This number rose even higher to 58 in the most recent 2019 ranking. There is not only an increase in numbers of Chinese universities among the top 500 but also a growth in numbers of Chinese universities that were listed among top 201-300 and 151-200. More progress is noted from the increased number of Chinese universities ranked among top 200 in recent years. For example, in 2004 there was no Chinese university standing at the top 200; however, by 2013 its number had expanded to five (Huang, 2015) and even further to 17 in 2019. 


\section{Method}

\subsection{Subject Selection}

Building on a history of over 110 years, Nanjing Agricultural University (NAU) is a pioneer of modern agricultural education, research, and extension work and the first institution in China to offer four-year bachelor programs in agricultural disciplines as well. The university has more than 2,700 faculty and staff members and over 25,500 full-time students. Among its faculty and staff are more than 27 people who either have been recruited through China's Recruitment Program of Global Experts or have been honored with the National Science Fund for Distinguished Young Scholars (Nanjing Agricultural University, 2013). It is also home to seven national research platforms, including the State Key Laboratory of Crop Genetics and Germplasm Enhancement. According to the results of the $4^{\text {th }}$ National First-level Discipline Evaluation announced by the Ministry of Education in December 2017, seven academic disciplines offered at NAU were graded in the A category, ranking NAU $11^{\text {th }}$ among Chinese universities nationwide. NAU also proposed to set up a World Agriculture Prize for outstanding contributions to research and innovation in agriculture and life sciences, which was officially established by the Global Confederation of Higher Education Association for the Agricultural and Life Sciences (GCHERA) on October $28^{\text {th }}, 2012$. In addition, the most recent analysis of research citations by Thomson Reuters Essential Science Indicators found NAU among the top 1\% of institutions in the fields of Environment and Ecology, Biology and Biochemistry, Engineering, Microbiology, Molecular Biology and Genetics, and Chemistry and among the top 1\%o of institutions in the fields of Agricultural Sciences and Plant and Animal Sciences. In the 2018 QS World University Rankings, NAU further jumped to the $47^{\text {th }}$ in Forestry and Agriculture, which is the first time for NAU to be ranked among the top 50. Besides, NAU is ranked number 9 in the Best Global Universities for Agricultural Sciences rankings, according to the U.S. News and World Report 2019 (U.S. News and World Report, 2019).

Nanjing Agricultural University is also chosen because it holds a unique position in the Chinese higher education system. China, in the past 40 years has risen rapidly, not only to the fastest-growing major economy but also to the world's largest agricultural economy. According to Lohmar, Gale Jr, Tuan, and Hansen (2009), agricultural reforms had a fundamental role in China's economic resurgence. Agricultural universities in China, as institutions of innovation and cultivation of top talents in agriculture science, had a very central role in this process. NAU, in particular, thanks to the efforts and economic and social benefits it has created, it has repeatedly been honored a national model in contributing to the national strategy of revitalizing agriculture through science and education. NAU was therefore selected as a 211 Project, one of the top 100 universities in China that the government has prioritized for research funding, discipline construction, and administrative supervision.

In 2014, NAU was listed among the first pilot universities under China's Excellent Agricultural and Forestry Talent Education and Training Program and later selected as a Chinese Ministry of Education double world-class project university, with double first-class status in certain disciplines such as in crop science and other agricultural courses (Nanjing Agricultural University, 2013).

As an agricultural research university aiming to achieve world-class status (Liu, Kipchumba, \& Liu, 2016), NAU holds a unique position not only in the Chinese higher education system but also in the global higher education system. It is this and all the above features that make NAU an interesting case to look into.

\subsection{Data Collection and Analysis}

This study uses a quantitative case study method, which is considered a suitable primary method in exploring a contemporary phenomenon and to provide an analysis of the essential factors, processes, and relationships involved in the phenomenon (Rashid, Rashid, Warraich, Sabir, \& Waseem, 2019; Zha, Wu, \& Hayhoe, 2019). Punch (2013) also noted that the case study is a valuable method for tackling "how do?" questions by describing real-life phenomena. Our study, which seeks to investigate how NAU has made progress towards attaining world-class research status, therefore finds the case study method as most appropriate to describe the efforts and processes taking place in NAU.

This research is based on data from the annual report of science and technology of Nanjing Agricultural University, which was provided by the NAU Academy of Science. University data over a period of nine years from 2008 to 2016 was analyzed for the efforts that NAU has put in place in order to improve the quality of agricultural research in various aspects: funding for research, promoting internationalization, motivating researchers by giving awards, and supporting participation in international academic conferences. 


\section{Results}

The status of funding, publications, awards, research collaboration, conferences, and patents for Nanjing Agricultural University are summarised in the appendix.

\subsection{Funding}

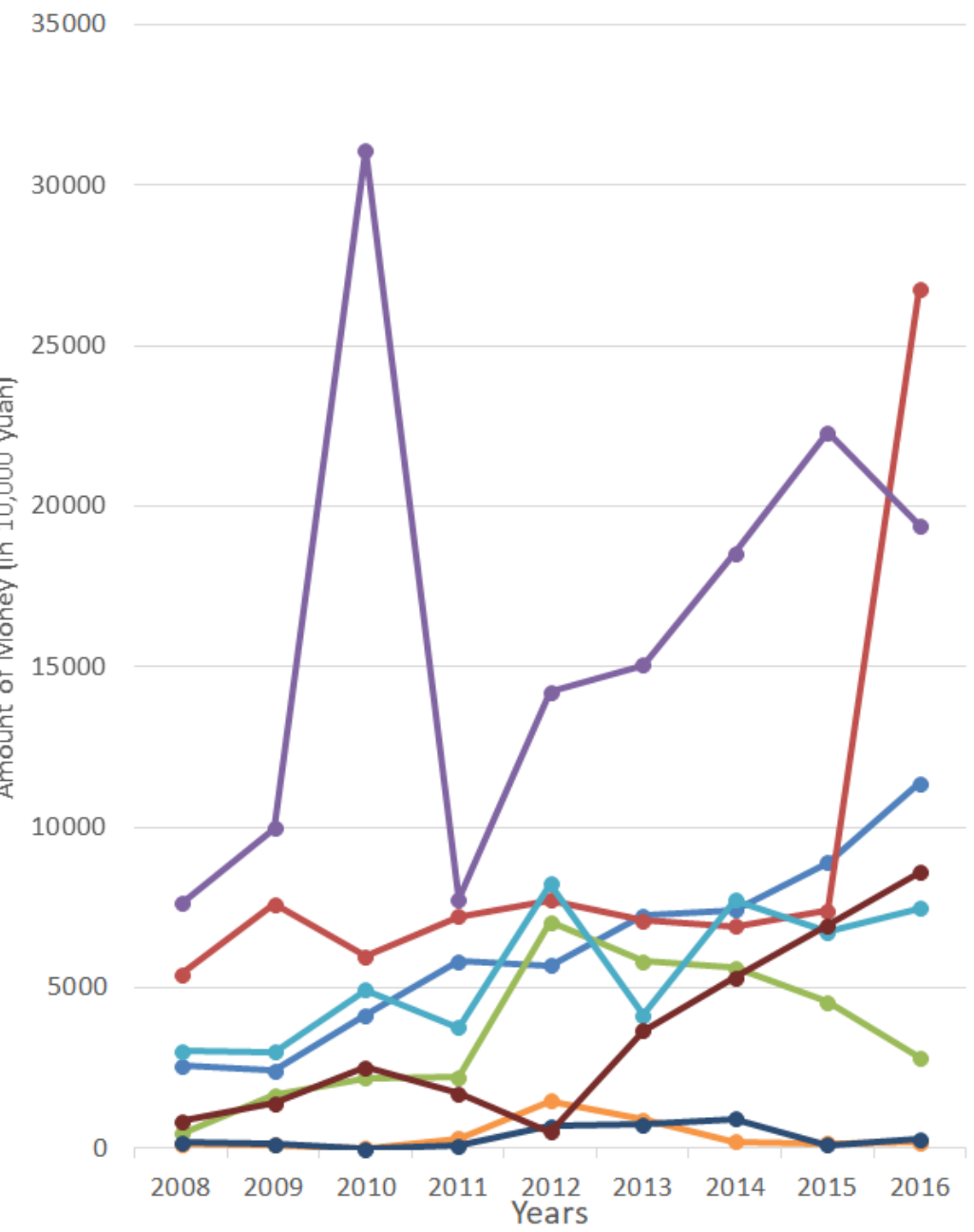

Figure 1. The trend of the different sources of research funds

Figure 1. Shows the different sources of research funding at Nanjing Agricultural University. A total of six government agencies have been funding the University. There is also some additional funding from what has been classified as others. The total contribution from the government agencies alone over the years is shown in Table 1

Table 1. Funds from government agencies over the years

\begin{tabular}{llllllllll}
\hline Year & 2008 & 2009 & 2010 & 2011 & 2012 & 2013 & 2014 & 2015 & 2016 \\
\hline $\begin{array}{l}\text { Amount (in } \\
10,000 \text { Yuan) }\end{array}$ & $19,460.5$ & $24,888.1$ & $48,451.4$ & $27,260.3$ & $45,124.4$ & $41,053.4$ & $47,416.21$ & $50,178.61$ & $68,371.05$ \\
\hline
\end{tabular}

Further, the Ministry of Agriculture has constantly taken the top position as a research funder, followed by the Ministry of Science and Technology, which surpasses the former in the year 2016. The other sources show an increase in trend. 


\section{A scatter plot of allocated funds and Time}

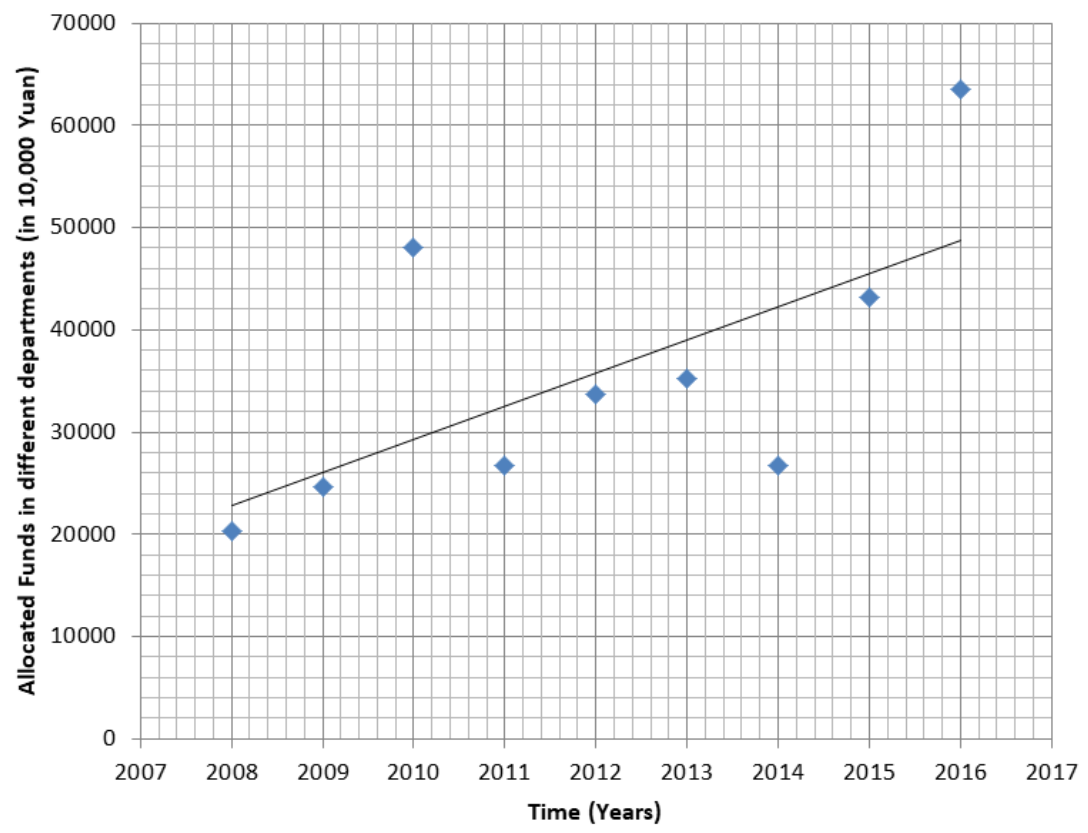

Figure 2. The trend of the total amount of research funds in NAU over nine years

Figure 2 shows the trend in total research funds allocated to Nanjing Agricultural University from 2008 to 2016. It can be noted that there has been a general increase over that period. Moreover, the annual total amount of money for research has doubled over in less than ten years, and the trend shows that for the past three years, there has been a rapid increase.

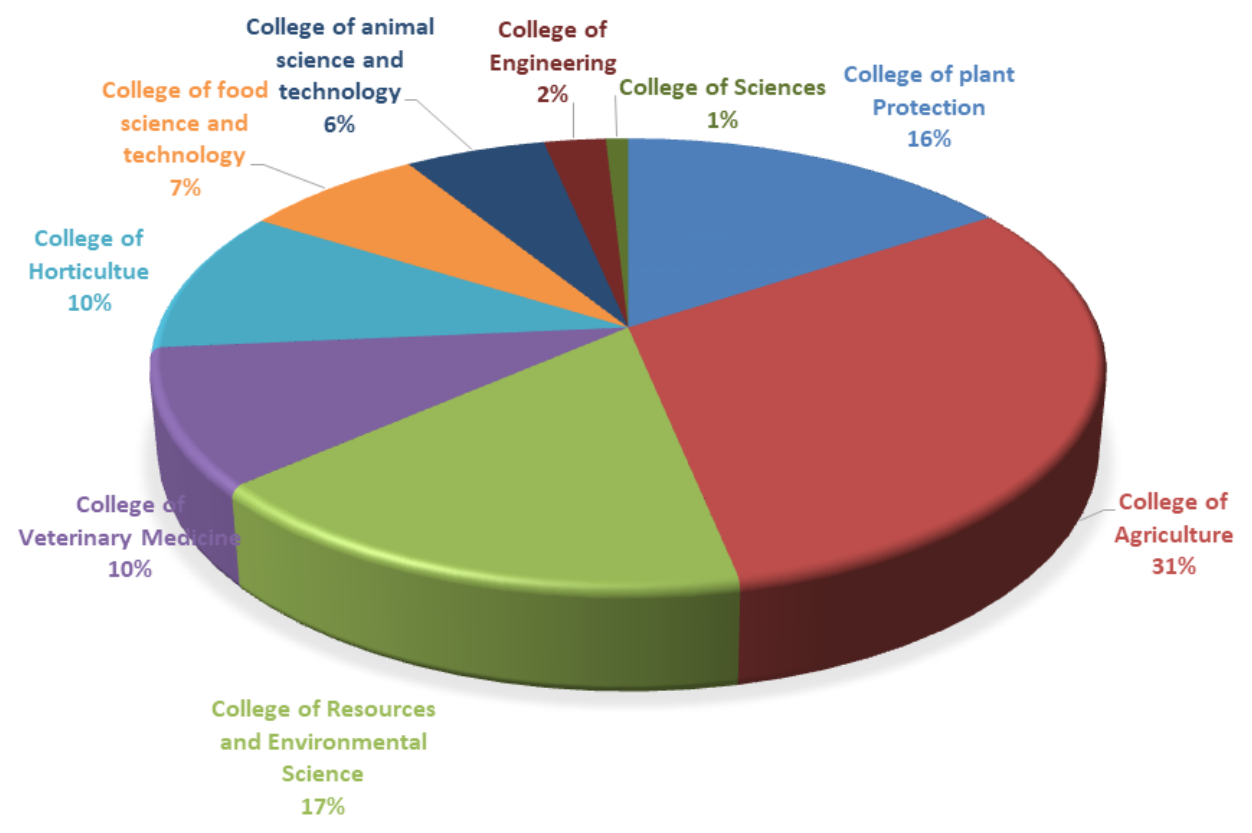

Figure 3. Allocation of funds per college

Figure 3 shows the division of research funds among science departments in the nine years from 2008 to 2016 . The college of Agriculture scoops the largest share of $31 \%$ of funds followed by the College of Resources and Environmental Sciences with 17\%, the College of Plant Protection with 16\%, and the College of Horticulture, which gets $10 \%$. The least funded colleges include the College of Sciences with $1 \%$ and the College of Engineering with $6 \%$. 


\subsection{Publications}

Total College Publications in International Journals

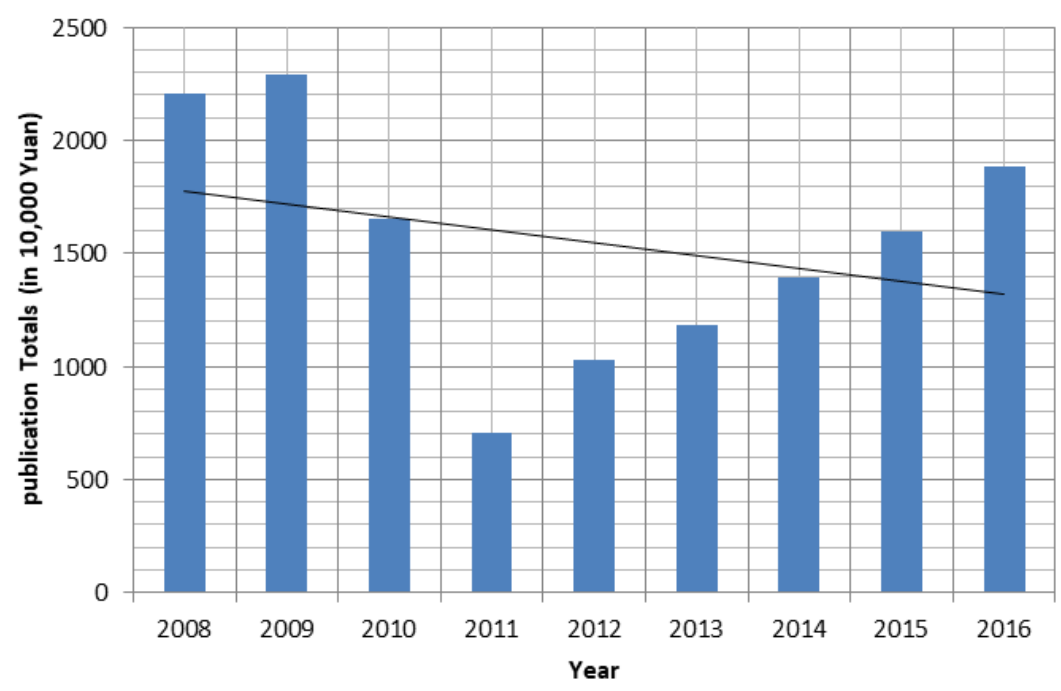

Figure 4. Total college international publications in 9 years

Figure 4 shows the number of publications in international journals indexed by the Social Sciences Citation Index (SSCI), Science Citation Index (SCI), Engineering Index (EI), and the Index to Scientific and Technical Proceedings (ISTP) during the study period. NAU counts the number of publications published in the academic journals indexed by SSCI, SCI, EI, and ISTP per scholar, and then compiles the total number from all the university departments, which gives the total annual number of publications in international journals. It is observed that the number of publications was highest between the years 2008 and 2009, with the years 2010 and 2011 registering the biggest drop. It is also evident that for the past four years following 2011, there is a rise in the number of papers published, with the number rising from 792 scientific publications in 2011 to 1,883 in 2016 . As such, there is an upward trend after a major decline in 2011. This goes to show that there is an increased acceptance of academic publications as an indicator of scholarly performance.

Table 2. Number of publications in international journals by discipline in NAU, 2008-2016

\begin{tabular}{llllllllll}
\hline Year & 2008 & 2009 & 2010 & 2011 & 2012 & 2013 & 2014 & 2015 & 2016 \\
\hline Sciences & 1,821 & 1,918 & 1,363 & 619 & 739 & 853 & 1,103 & 1,266 & 1,552 \\
Arts \& Social Sciences & 389 & 371 & 281 & 173 & 287 & 329 & 285 & 312 & 304 \\
\hline
\end{tabular}

Academic staff from the sciences are the major contributors to publications in NAU, as indicated by Table 2 . Academic staff from the arts and social sciences are unable to match their strong achievements in this area. However, according to Tan and Goh (2014), this should not be construed as a lack of research outputs by academics from the arts and social sciences but more because of disciplinary variation. Natural scientists publish more of their work in journals than do social scientists who also write books, book chapters, reports, and other genres (Lillis \& Curry, 2013). 


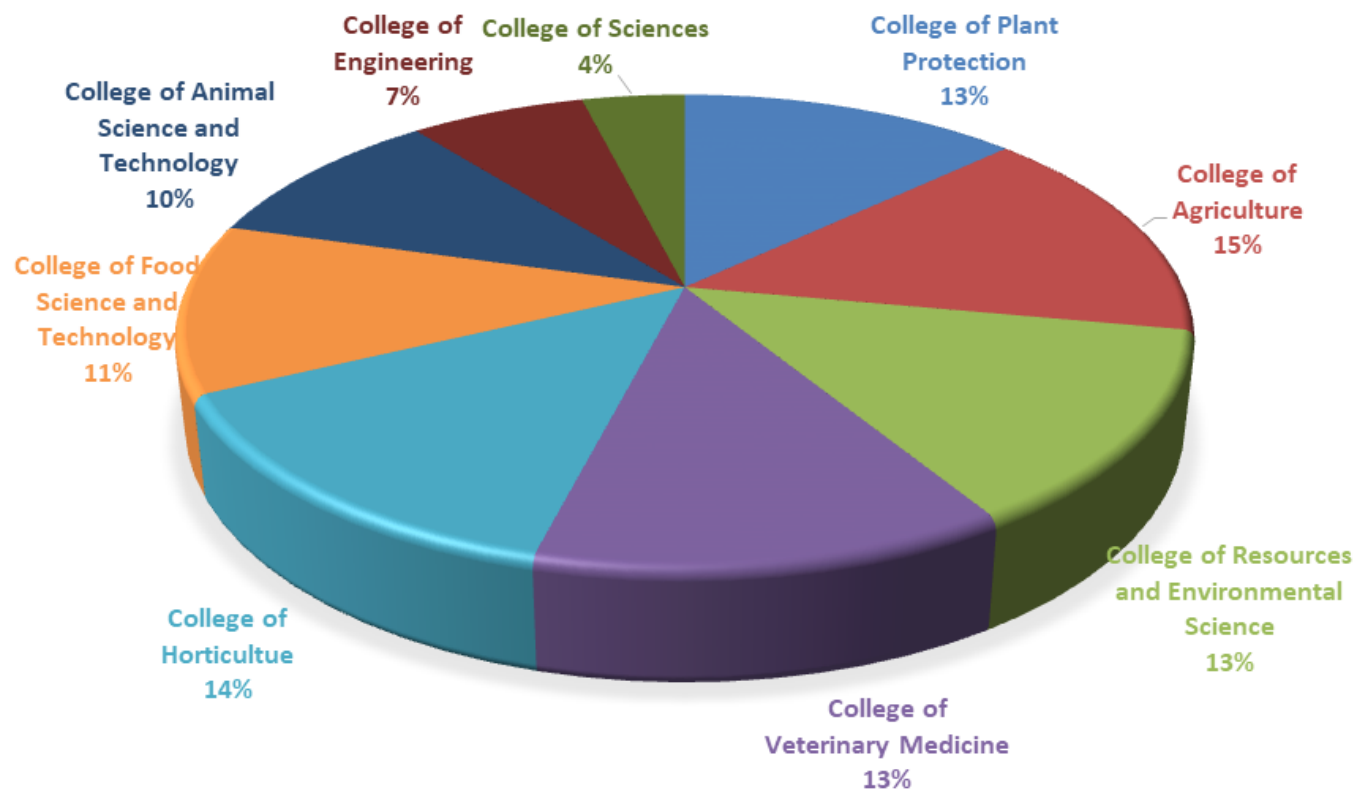

Figure 5. Percentage of total international publications per college

Figure 5 shows the total percentage of publications in international journals indexed by SSCI, SCI, EI, and ISTP per college. The College of Agriculture takes the lead with $15 \%$ of all scientific publications for the nine years, followed by the College of Horticulture with $14 \%$, and both the College of Plant Protection and College of Resources and Environmental Sciences with $13 \%$.

\subsection{Patents}

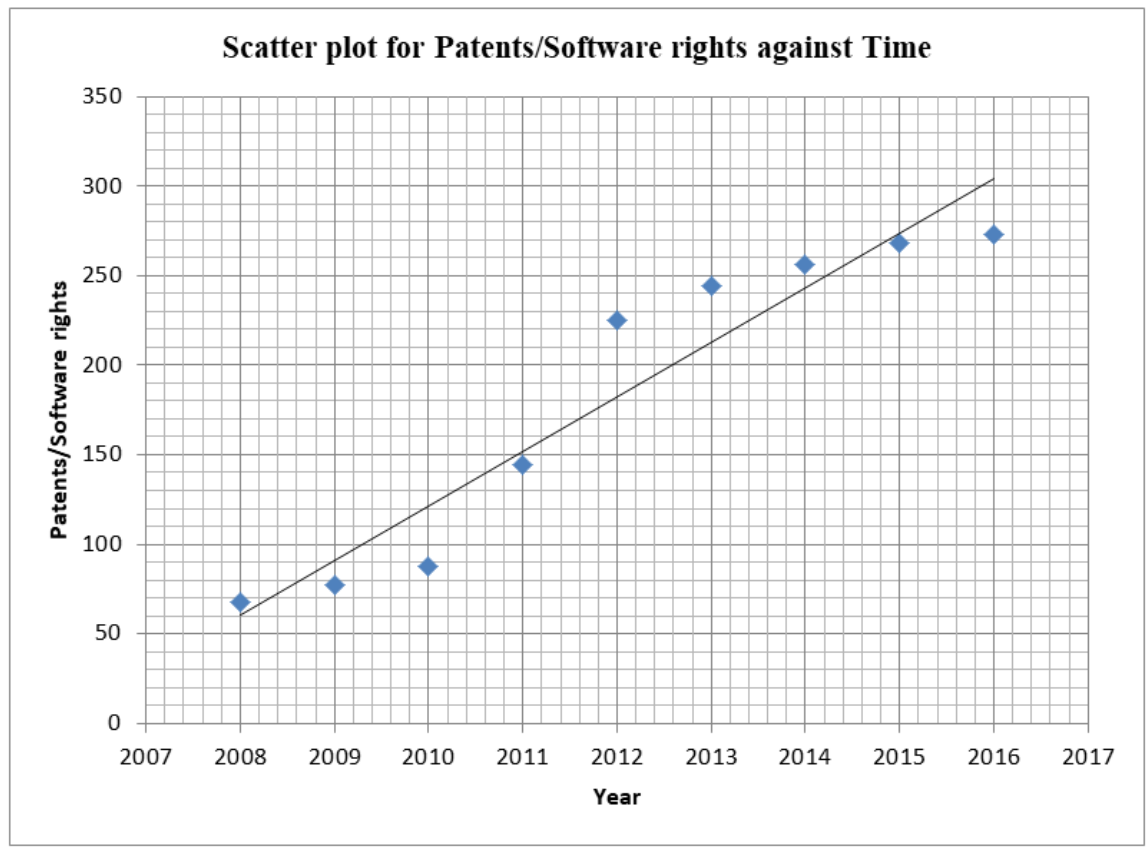

Figure 6. Patents and software rights

Figure 6 shows the patent and software rights production trend in Nanjing Agricultural University over the years. There is a clear rise in the quantity of the patents produced, which is an indicator that research production in the university is not only being supported and sustained but also increasing steadily. Such a trend is significant in developing world-class status. The prediction is that the university will continue sustaining its efforts and will successfully rise to world-class status. 


\subsection{Internationalization and Collaboration in Research}

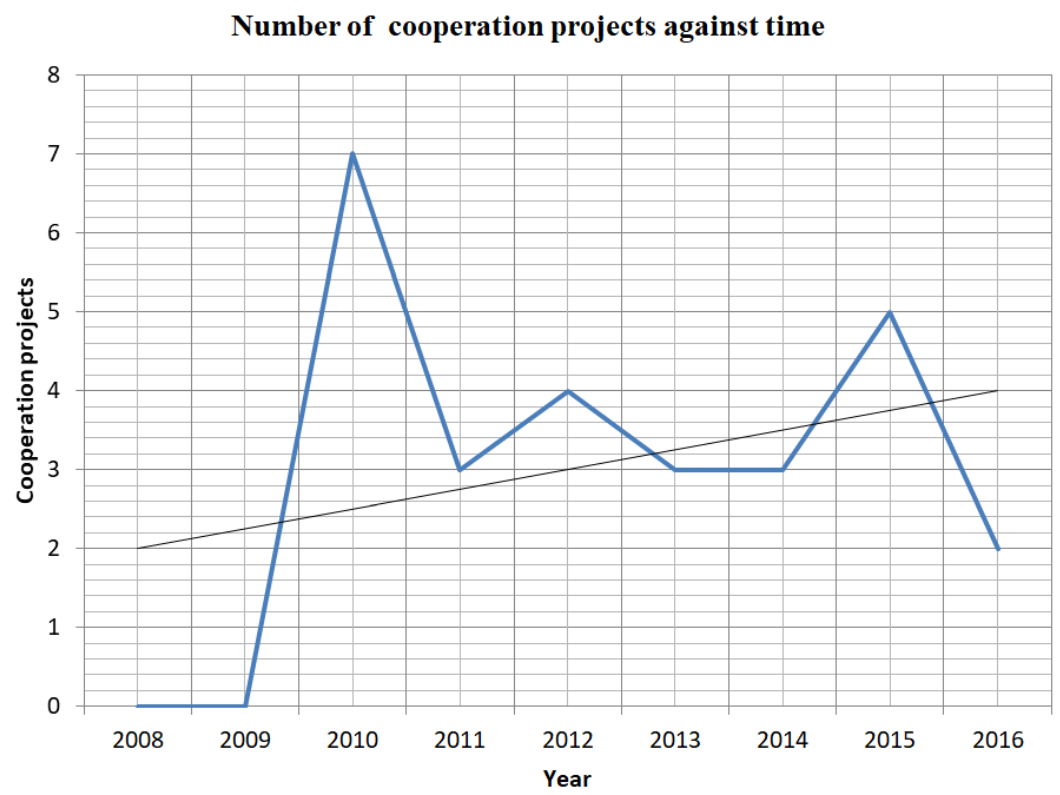

Figure 7. International science and technological research cooperation

Figure 7 shows the international science and technological research cooperation in the university. On average, the University has been hosting an average of 3 research cooperation projects during the duration under review. However, the precise number of research cooperation projects per year has been wavering a lot from a minimum of zero in 2008 and 2009, and a maximum of 7 in 2010.

\subsection{Awards for Excellent Research}

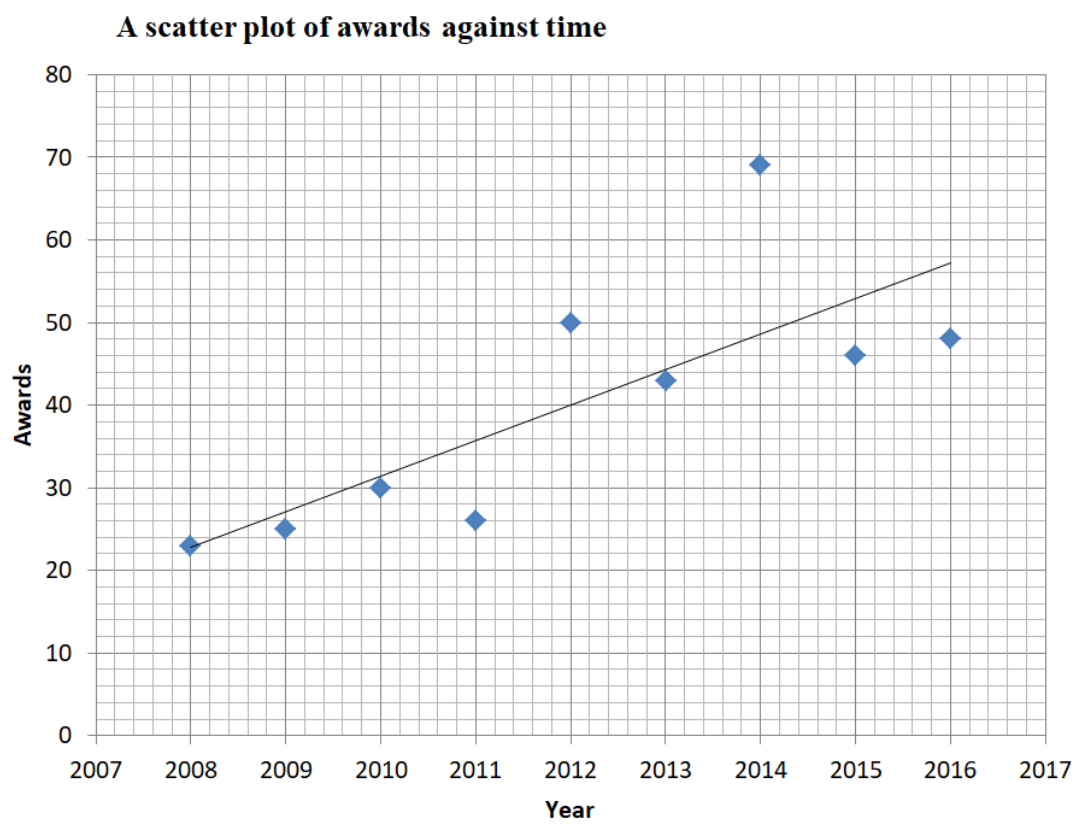

Figure 8. Awards

Figure 8 shows the trend of provincial and state awards for excellent researchers between the years 2008 and 2016. The awards range from provincial level recognition such as the Jiangsu Provincial People's Government awards for Science and Technology Progress, to the more prestigious national awards awarded by different state divisions and ministries such as the Ministry of Education Excellent Achievements Award for Scientific 
Research in Institutions of Higher Learning. During that study period, Nanjing Agricultural University achieved the highest number of awards in the year 2014 while the lowest number of awards was recorded in the year 2008. In general, there is a progressive increase in the number of awards during the study period, recognizing NAU as a lead institution.

\subsection{International Academic Conferences}

A scatter plot for number of international academic conferences against time

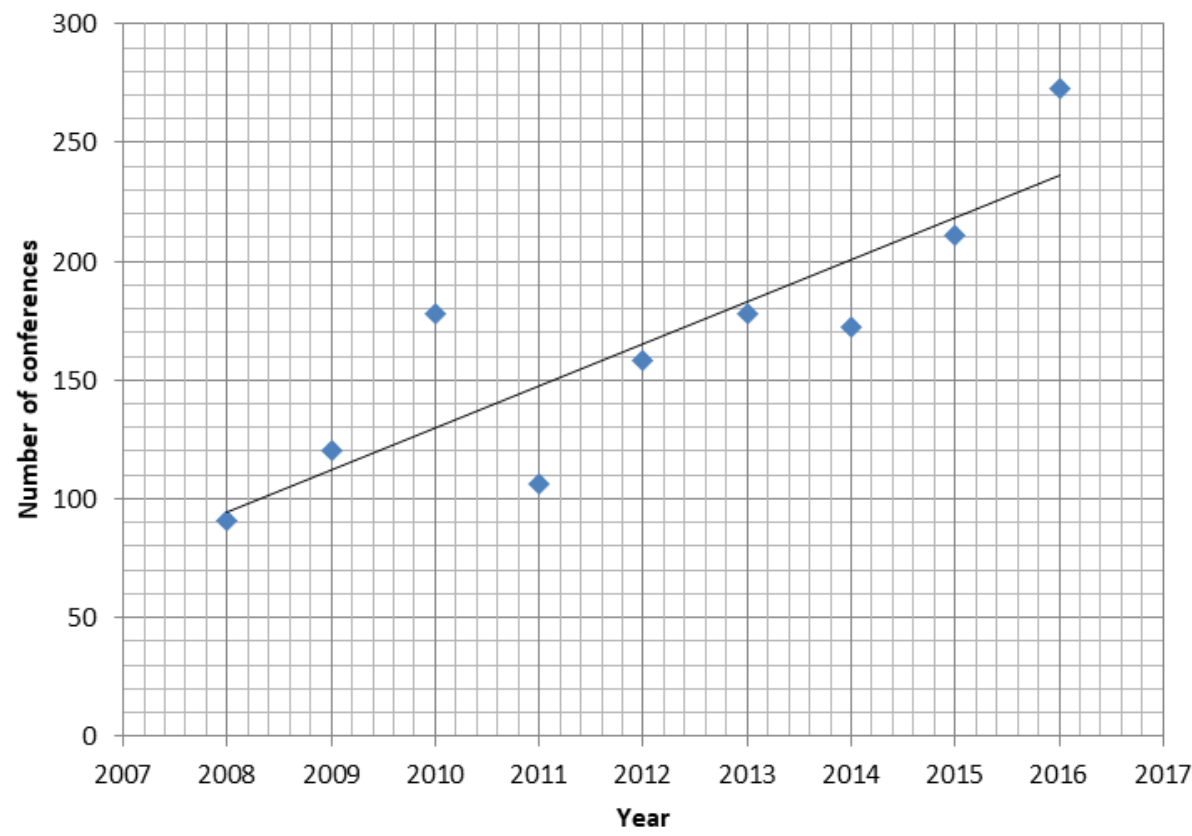

Figure 9. Number of international academic conferences

Figure 9 shows the participation in international academic conferences for Nanjing Agricultural University. A total of 91 international academic conferences were recorded in 2008. The number of conferences has been rising steadily with time. In the year 2016, a total of 273 conferences were recorded. This shows a rise in international academic conference participation, which, for a developing university, is a good sign.

\section{Discussion}

\subsection{Funding}

Earlier reports (H. Zhang et al. (2013) indicate that China is investing considerable resources in its universities, and that is having an impact. An analysis of funding for Nanjing Agricultural University tends to agree with this. During the study period, the university has received funding from six different government entities. Although some of these sources (for example, the Ministry of Agriculture) have varied the level of funding considerably, the total funding received by the university has been increasing steadily from 203,163,000 Yuan in 2008 to $769,637,900$ Yuan in 2016. It can be seen that regarding sustaining university research, the fund sources have all ensured their contribution in all the years. Also, the amount of funds received by the university has more than doubled over in less than ten years. There is a clear picture of the intensity of support that research is being accorded in the University. From this study, however, it was not certain whether this funding is adequate for university needs.

How institutions organize and prioritize their resources is an important factor in attaining world-class status. It may affect research output, for example, the quality and quantity of publications and other factors such as the participation of colleges in academic conferences, research co-operation activities, and college awards to excellent researchers. Being an agricultural research university, Nanjing Agricultural University is bound to support agricultural-related research. It is possibly for this reason that the College of Agriculture has received the 
largest share of the University funds.

\subsection{Publications}

According to $\mathrm{H}$. Zhang et al. (2013), there has been a remarkable expansion of Chinese publications in international journals, to an extent that China has overtaken the UK in article publications in 2008 and only trails the US. This can largely be explained by the fact that research publications have received much recognition and interest in China in the last few decades. Almost all universities in Mainland China set down a specified number of publications as a precondition for promotion to an associate professorship or full professorship (Flowerdew, 2015). Also, one of the requirements graduate students need to fulfil before graduation is publish in highly-ranked journals, with top universities even stipulating the number of papers required and in specific impact factor journals $(\mathrm{Li}, 2016)$. The current study finds that Nanjing Agricultural University has not been left behind. The number of papers published (Figure 4), has risen from 792 scientific publications in 2011 to 1,883 in 2016. If this trend is sustained over time, the university then will achieve more and more publications and hence, ranking among the foremost in the world.

From the results of Figure 3 (allocation of funds per college) and Figure 5 (percentage of total publications per college), it is evident that the level of funding affects the number of publications. The College of Agriculture, which received the highest amount of funds during the nine years, also achieved the highest number of publications. The other top colleges in scientific publications also report a high amount of funds allocated to them. On the other hand, the colleges that received the least percentage of funds also report the least number of scientific publications. For example, the College of Sciences, the least funded college in the nine years, produces just $4 \%$ of publications. The College of Engineering follows close by with 7\%, the second least percentage of scientific publications. Though there might be some other affecting variables, adequate funding is essential for research, which in turn translates into more publications.

The effect of funding on the number of publications may partly explain where for example a high level of funding between 2008 and 2010 saw to high levels of publications in the three years. Though there could be some other intervening variables, it is highly probable that there was favorable funding in the previous years was high.

\subsection{Patents}

The results in Figure 6 show a steady rise in the quantity of the patents produced. This is an indicator that research results are tangible and good quality. If such a trend is sustained it may have a significant impact on the economy. The rising trend (Figure 6) closely resembles that of funds (Figure 2), suggesting a positive correlation between the level of funding and the number of patents. Such a trend is highly significant in developing world-class status. The prediction is that the university will continue sustaining its efforts and will successfully rise to world-class status.

\subsection{International Collaborations}

The results of Figure 7 indicate that there has not been a steady growth in international science and technological research cooperation in the university. Co-operations not only lead to better research but also encourage staff mobility, which is a key factor in developing world-class research universities. Co-operations are, therefore, significant in attaining world-class university status. Hence the sustainability of these projects in the university is a necessary feature. For a university on the road towards attaining world-class status, it is important to consistently maintain research co-operations.

\subsection{Awards for Excellent Research}

Figure 8 shows the trend of awards for excellent researchers between the years 2008 and 2016. It is evident that the Chinese government and the University have consistently, from year to year, been awarding staff for good research. In general, there is a progressive increase in the number of awards during the study period.

Awarding the high research performance among staff is one way in which a university or government can motivate better research. A study on the efforts of the Universiti Sains Malaysia (USM) or the Science University of Malaysia at rising to world-class status reveals that indeed, an incentive put in place by the university to award excellent research led to improved research (Tan \& Goh, 2014). The number of publications in citation-indexed journals among USM academic staff increased in such a way that the average number of publications in citation-indexed journals had exceeded one publication per academic staff in a period of 10 years (Tan \& Goh, 2014). This, in turn, leads to increased research production, more research publications and more patents. This explains the close resemblance in the trends of Figure 8 (awards), Figure 6 (patents), and the publications especially between the years 2011 and 2015 (Figure 4). 
Awards alone may not be an adequate stimulus for research. Adequate funding, among other factors, is also required for results to be realized. This may partly explain where the trend in awards (Figure 8) also closely resembles that of funds (figure 2).

\subsection{Academic Conferences}

The results in Figure 9 indicate that the number of conferences has been rising steadily with time such that even where there is a decline in one year, the decline is compensated in the other years. For example, the slight decline in 2011 is compensated for by the higher number of conferences in 2010 and 2012.

Academic conferences provide an environment of sharing academic and technological achievements as well as challenges and potential research topics. The trend observed in the results for NAU is encouraging.

\subsection{Policy Implications}

The policies that the management of NAU has put in place regarding research requirements, publications and participation in international academic conferences have further led to the progress of the university towards attaining world-class status. For instance, by prioritizing the number of publications during promotion to an associate professorship or full professorship, the university plays a major role in motivating the quantity and quality of research. Therefore, in order to progress towards attaining world-class status, in addition to government support, it is clear that university leadership and management is of importance, and may play a fundamental role in accelerating the whole process.

\section{Conclusions and Recommendations}

In conclusion, NAU sought to achieve the highest possible standards in research excellence in order to build a world-class research university. Further, it has consistently sustained these efforts, a necessary characteristic in the rather complex long road to attaining world-class status. This is in alignment with China's national higher education decades-old dream. It is concluded that with realistic planning and sustainability, it is possible to keep improving and getting nearer and nearer to achieving the worthy and vital objective of world-class excellence in university research.

The process of building a world-class research university needs, however, to be accelerated. NAU has identified and implemented appropriate strategies to improve research quality and achieve world-class status. The accomplishment of this status inevitably involves the improvement and sustainability of these efforts towards achieving high research standards. Well-oriented strategic plans have been adopted to improve the status of NAU with regard to research excellence.

Funding is acknowledged as a vital factor for preparing to attain the world-class status. Funding from the government is integral to the conduction of university research in China. There is a clear relationship between funding and other indicators. For instance, the publications increased with funding. Also, the colleges allocated more funds in turn, posted more publications.

A significant rise in progress towards attaining world-class research status is attributed to the sustainability of these efforts. As noted by various authors, change does not take place overnight. Besides, the process of creating a world-class research university is a long process that requires time and consistency. Thus, research into the sustainability of these efforts is very important. However, there does not seem to be any clear set of complementary factors defining sustainability in efforts towards attaining world-class status (Z. Liu et al., 2019).

\section{Acknowledgments}

The work described in this paper was supported by the Humanities and Social Sciences Grant of Fundamental Research Funds for the Central Universities of Nanjing Agricultural University (Project number: SKYC2019002).

Profound thanks go to the College of International Education, the Academy of Science, the Office of International Relations the academic staff from the College of Public Administration, Nanjing Agricultural University, and Mr. Joel Irungu Muriu for their guidance and overall comprehensive support to complete this study.

\section{References}

Altbach, P. (2003). The costs and benefits of world-class universities. International Higher Education, 33. https://doi.org/10.6017/ihe.2003.33.7381

Altbach, P. G., \& Salmi, J. (2011). The road to academic excellence: The making of world-class research universities. The World Bank. https://doi.org/10.1596/978-0-8213-8805-1 
Asongu, S. A., \& Nwachukwu, J. C. (2018). PhD by publication as an argument for innovation and technology transfer: With emphasis on Africa. Higher Education Quarterly, 72(1), 15-28. https://doi.org/10.1111/hequ.12141

Bejinaru, R., \& Prelipcean, G. (2017). Successful strategies to be learnt from world-class universities. Paper presented at the Proceedings of the International Conference on Business Excellence. https://doi.org/10.1515/picbe-2017-0037

Branigan, J. J., Harvie, C., Michalas, G., \& Ramezani Khansari, F. (2016). Leading locally, competing globally: measuring the University of Wollongong's contribution to economic and social prosperity in the Illawarra and beyond-2016 update.

Brusilovsky, P., Oh, J. S., López, C., Parra, D., \& Jeng, W. (2017). Linking information and people in a social system for academic conferences. New Review of Hypermedia and Multimedia, 23(2), 81-111. https://doi.org/10.1080/13614568.2016.1179796

Chellaraj, G., Maskus, K. E., \& Mattoo, A. (2005). The contribution of skilled immigration and international graduate students to US innovation: The World Bank. https://doi.org/10.1596/1813-9450-3588

Choi, J., Jang, D., Jun, S., \& Park, S. (2015). A predictive model of technology transfer using patent analysis. Sustainability, 7(12), 16175-16195. https://doi.org/10.3390/su71215809

Cremonini, L., Westerheijden, D. F., Benneworth, P., \& Dauncey, H. (2014). In the shadow of celebrity? World-class university policies and public value in higher education. Higher Education Policy, 27(3), 341-361. https://doi.org/10.1057/hep.2013.33

Czarniewski, S. (2015). Mechanisms for the Creation of Innovation in Contemporary Business and Economy. International Journal of Academic Research in Accounting, 5(1), 33-38. https://doi.org/10.6007/IJARAFMS/v5-i1/1415

Dictionary, C. (Ed.). Sustainability. Retrieved from https://dictionary.cambridge.org/dictionary/english/sustainability

Dillon, T. (2009). Patent Work: The Other Side of Invention. Occupational Outlook Quarterly, 53(3), 18-25.

Flowerdew, J. (2015). Some thoughts on English for research publication purposes (ERPP) and related issues. Language Teaching, 48(2), 250-262. https://doi.org/10.1017/S0261444812000523

Frey, B. S., \& Neckermann, S. (2008). Academics appreciate awards-a new aspect of incentives in research. Retrieved from https://EconPapers.repec.org/RePEc:ces:ceswps:_2531

Hayden, M. C., Weiß, M., Pechriggl, A., \& Wutti, D. (2018). Insights Into University Knowledge Transfer in the Social Sciences and Humanities (SSH) and Other Scientific Disciplines-More Similarities Than Differences. Frontiers in Research Metrics and Analytics, 3, 32. https://doi.org/10.3389/frma.2018.00032

Henderson, E. F. (2015). Academic conferences: Representative and resistant sites for higher education research. Higher Education Research \& Development, 34(5), 914-925. https://doi.org/10.1080/07294360.2015.1011093

Hickson, I., Mark. (2006). Raising the Question\# 4 Why Bother Attending Conferences? Communication Education, 55(4), 464-468. https://doi.org/10.1080/03634520600917632

Huang, F. (2015). Building the world-class research universities: A case study of China. Higher Education, 70(2), 203-215. https://doi.org/10.1007/s10734-015-9876-8

Huang, F. (2017, September 29). Double world-class project has more ambitious aims. University World News. Retrieved from https://www.universityworldnews.com/post.php?story=2017092913334471

Hussain, T., Eskildsen, J., Edgeman, R., Ismail, M., Shoukry, A. M., \& Gani, S. (2019). Imperatives of Sustainable University Excellence: A Conceptual Framework. Sustainability, 11(19), 5242. https://doi.org/10.3390/su11195242

Ileritürk, D., \& Kincal, R. Y. (2018). Analysis of PISA 2012 Participant Countries' Success Rankings in Terms of Their Patent Productivities. International Journal of Instruction, 11(4), 191-206. https://doi.org/10.12973/iji.2018.11413a

Kalanje, C. M. (2006). Role of intellectual property in innovation and new product development. World Intellectual Property Organization.

Kalar, B., \& Antoncic, B. (2015). The entrepreneurial university, academic activities and technology and 
knowledge transfer in four European countries. Technovation, 36, 1-11. https://doi.org/10.1016/j.technovation.2014.11.002

Leslie, L. L., Slaughter, S., Taylor, B. J., \& Zhang, L. (2012). How do revenue variations affect expenditures within US research universities? Research in Higher Education, 53(6), 614-639. https://doi.org/10.1007/s11162-011-9248-x

Lillis, T., \& Curry, M. J. (2013). Academic writing in a global context: The politics and practices of publishing in Englis. Routledge. https://doi.org/10.4324/9780203852583

Li, Y. (2016). "Publish SCI papers or no degree": practices of Chinese doctoral supervisors in response to the publication pressure on science students. Asia Pacific Journal of Education, 36(4), 545-558. https://doi.org/10.1080/02188791.2015.1005050

Liu, W. (2018). The Construction of "Double First-Class" against the Background of New Era-A Case Study of Zhongnan University of Economics and Law. Paper presented at the 4th Annual International Conference on Management, Economics and Social Development (ICMESD 2018). https://doi.org/10.2991/icmesd-18.2018.79

Liu, Z., Kipchumba, S. K., \& Liu, L. (2016). Paths for world-class universities in agricultural science. Higher Education, 71(1), 97-118. https://doi.org/10.1007/s10734-015-9891-9

Liu, Z., Moshi, G. J., \& Awuor, C. M. (2019). Sustainability and Indicators of Newly Formed World-Class Universities (NFWCUs) between 2010 and 2018: Empirical Analysis from the Rankings of ARWU, QSWUR and THEWUR. Sustainability, 11(10), 2745. https://doi.org/10.3390/su11102745

Lohmar, B., Gale Jr, H. F., Tuan, F. C., \& Hansen, J. M. (2009). China's ongoing agricultural modernization: Challenges remain after 30 years of reform.

Luo, Y. (2013). Building world-class universities in China. In Institutionalization of world-class university in global competition (pp. 165-183). Springer. https://doi.org/10.1007/978-94-007-4975-7

Marginson, S. (2017). The world-class multiversity: Global commonalities and national characteristics. Frontiers of Education in China, 12(2), 233-260. https://doi.org/10.1007/s11516-017-0018-1

Mintrom, M. (2008). Managing the research function of the university: pressures and dilemmas. Journal of Higher Education policy and management, 30(3), 231-244. https://doi.org/10.1080/13600800802155028

Nanjing Agricultural University. (2013). Introduction: Welcome to Nanjing Agricultural University. Retrieved from http://zsxx.njau.edu.cn/English/Introduction.htm

Ngok, K., \& Guo, W. (2008). The quest for world class universities in China: Critical reflections. Policy Futures in Education, 6(5), 545-557. https://doi.org/10.2304/pfie.2008.6.5.545

Nicolson, D. J. (2016). Academic conferences as neoliberal commodities. Springer. https://doi.org/10.1007/978-3-319-49190-5

Ota, H. (2018). Internationalization of Higher Education: Global Trends and Japan's Challenges. Educational Studies in Japan, 12, 91-105. https://doi.org/10.7571/esjkyoiku.12.91

Pang, L. (2018). How Tsinghua Became a World Class Research University: A Case Study on the Impact of Rankings on a Chinese Higher Education Institution.

Peters, M. A., \& Besley, T. (2018). China's double first-class university strategy: 双一流. In: Taylor \& Francis. https://doi.org/10.1080/00131857.2018.1438822

Punch, K. F. (2013). Introduction to social research: Quantitative and qualitative approaches: sage.

Rashid, Y., Rashid, A., Warraich, M. A., Sabir, S. S., \& Waseem, A. (2019). Case Study Method: A Step-by-Step Guide for Business Researchers. International Journal of Qualitative Methods, 18, 1609406919862424. https://doi.org/10.1177/1609406919862424

Reddy, K., Xie, E., \& Tang, Q. (2016). Higher education, high-impact research, and world university rankings: A case of India and comparison with China. Pacific Science Review B: Humanities and Social Sciences, 2(1), 1-21. https://doi.org/10.1016/j.psrb.2016.09.004

U.S. News and World Report (2019). Best Global Universities for Agricultural Sciences. Retrieved from https://www.usnews.com/education/best-global-universities/search?region=\&subject=agricultural-sciences \&name $=$ 
Rossi, F., \& Rosli, A. (2015). Indicators of university-industry knowledge transfer performance and their implications for universities: evidence from the United Kingdom. Studies in Higher Education, 40(10), 1970-1991. https://doi.org/10.1080/03075079.2014.914914

Salem, M. I. (2014). The role of universities in building a knowledge-based economy in Saudi Arabia. International Business \& Economics Research Journal (IBER), 13(5), 1047-1056. https://doi.org/10.19030/iber.v13i5.8771

Schulte, B. (2019). Innovation and control: universities, the knowledge economy and the authoritarian state in China. Nordic Journal of Studies in Educational Policy, 5(1), 30-42. https://doi.org/10.1080/20020317.2018.1535732

Shen, G. (2015). Building world-class universities in China: From the view of national strategies. The Global University Network for Innovation. Retrieved from www.guninetwork.org/resources/he-articles/building-world-class-universities-inchina-from-the-view-of-nati onal-strategies

Song, J. (2018). Creating world-class universities in China: Strategies and impacts at a renowned research university. Higher Education, 75(4), 729-742. https://doi.org/10.1007/s10734-017-0167-4

Stern, B. M., \& O'Shea, E. K. (2019). A proposal for the future of scientific publishing in the life sciences. PLoS biology, 17(2), e3000116. https://doi.org/10.1371/journal.pbio.3000116

Sverdrup, H., \& Svensson, M. G. (2002). Defining sustainability. In Developing principles and models for sustainable forestry in Sweden (pp. 21-32): Springer. https://doi.org/10.1007/978-94-015-9888-0

Tan, Y. S., \& Goh, S. K. (2014). International students, academic publications and world university rankings: the impact of globalisation and responses of a Malaysian public university. Higher Education, 68(4), 489-502. https://doi.org/10.1007/s10734-014-9724-2

Tayeb, O. (2016). Roadmap to Become a World-Class University. In Becoming a World-Class University (pp. 1-19): Springer, Cham. https://doi.org/10.1007/978-3-319-26380-9_1

Tierney, W. (2014). The challenge in becoming and staying a world-class university. In: University of Southern California.

Toman, M. A. (1992). The difficulty in defining sustainability. Resources, 106(Winter), 3-6.

Tsai, C.-W. (2017). China's rising research universities: a new era of global ambition. In: Taylor \& Francis. https://doi.org/10.1080/07294360.2017.1316663

Veugelers, R. (2017). The challenge of China's rise as a science and technology powerhouse. Retrieved from https://bruegel.org/wp-content/uploads/2017/07/PC-19-2017.pdf

Veugelers, R., \& Baltensperger, M. (2019). Europe-the Global Centre for Excellent Research: European Parliament.

Wang, Q., Cheng, Y., \& Liu, N. C. (2012). Building world-class universities: Different approaches to a shared goal. In Building World-Class Universities (pp. 1-10): Brill Sense. https://doi.org/10.1007/978-94-6209-034-7

Wang, Q. H., Wang, Q., \& Liu, N. C. (2011). Building world-class universities in China: Shanghai Jiao Tong university. In. https://doi.org/10.1596/9780821388051_CH02

Xie, Q., \& Freeman, R. B. (2019). Bigger Than You Thought: China's Contribution to Scientific Publications and Its Impact on the Global Economy. China \& World Economy, 27(1), 1-27. https://doi.org/10.1111/cwe.12265

Yang, R., \& Welch, A. (2012). A world-class university in China? The case of Tsinghua. Higher Education, 63(5), 645-666. https://doi.org/10.1007/s10734-011-9465-4

Zha, Q., Wu, H., \& Hayhoe, R. (2019). Why Chinese universities embrace internationalization: an exploration with two case studies. Higher Education, 1-18. https://doi.org/10.1007/s10734-019-00364-w

Zhang, H., Patton, D., \& Kenney, M. (2013). Building global-class universities: Assessing the impact of the 985 Project. Research Policy, 42(3), 765-775. https://doi.org/10.1016/j.respol.2012.10.003

Zhang, L., Bao, W., \& Sun, L. (2016). Resources and research production in higher education: A longitudinal analysis of Chinese universities, 2000-010. Research in Higher Education, 57(7), 869-891.

https://doi.org/10.1007/s11162-016-9410-6 
Zhao, B. (2018). State disinvestment in higher education: the impact on public research universities' patent applications.

Zhao, L. (2018). China's World-Class 2.0: Towards More Institutionalized and Participatory Policymaking? The Copenhagen Journal of Asian Studies, 36(1), 5-27. https://doi.org/10.22439/cjas.v36i1.5510

Zong, X., \& Zhang, W. (2019). Establishing world-class universities in China: deploying a quasi-experimental design to evaluate the net effects of Project 985. Studies in Higher Education, 44(3), 417-431. https://doi.org/10.1080/03075079.2017.1368475

\section{Appendix}

Key performance indicators for Nanjing Agricultural University

\begin{tabular}{|c|c|c|c|c|c|c|c|c|c|}
\hline & 2008 & 2009 & 2010 & 2011 & 2012 & 2013 & 2014 & 2015 & 2016 \\
\hline Funding (in 10,000 Yuan) & $19,460.5$ & $24,888.1$ & $48,451.4$ & $27,260.3$ & 45,1053 & $41,053.4$ & $47,416.21$ & $50,178.61$ & $68,371.05$ \\
\hline Academic publications & 2210 & 2289 & 1652 & 792 & 1026 & 1182 & 1391 & 1599 & 1883 \\
\hline Awards & 23 & 25 & 30 & 26 & 50 & 43 & 69 & 46 & 48 \\
\hline Research cooperation & 0 & 0 & 7 & 3 & 4 & 3 & 3 & 5 & 2 \\
\hline Academic conferences & 91 & 120 & 178 & 106 & 158 & 178 & 172 & 211 & 173 \\
\hline Patents & 63 & 77 & 88 & 144 & 225 & 244 & 256 & 268 & 273 \\
\hline
\end{tabular}

\section{Copyrights}

Copyright for this article is retained by the author(s), with first publication rights granted to the journal.

This is an open-access article distributed under the terms and conditions of the Creative Commons Attribution license (http://creativecommons.org/licenses/by/4.0/). 